\title{
Corrigendum: Comparative Analysis of DNA Methyltransferase Gene Family in Fungi: A Focus on Basidiomycota
}

\section{OPEN ACCESS}

Edited and reviewed by: Keqiang Wu

National Taiwan University, Taiwan

${ }^{*}$ Correspondence:

Gu Tingting

gutingting@njau.edu.cn

Yi Li

yi.li@uconn.edu

Specialty section:

This article was submitted to

Plant Genetics and Genomics,

a section of the journal

Frontiers in Plant Science

Received: 17 January 2017

Accepted: 20 January 2017

Published: 03 February 2017

Citation:

Huang R, Ding Q, Xiang Y, Gu T and Li Y (2017) Corrigendum: Comparative

Analysis of DNA Methyltransferase Gene Family in Fungi: A Focus on Basidiomycota.

Front. Plant Sci. 8:123.

doi: 10.3389/fpls.2017.00123

\begin{abstract}
Ruirui Huang ${ }^{1}$, Qiangqiang Ding ${ }^{1}$, Yanan Xiang ${ }^{2}$, Tingting $\mathrm{Gu}^{1 *}$ and $\mathrm{Yi}_{\mathrm{Li}}{ }^{1,3 *}$
1 State Key Laboratory of Plant Genetics and Germplas Enhancement and College of Horticulture, Nanjing Agricultural University, Nanjing, China, ${ }^{2}$ Laboratory of Plant Hormone, College of Life Sciences, Nanjing Agricultural University, Nanjing, China, ${ }^{3}$ Department of Plant Science and Landscape Architecture, University of Connecticut, Storrs, CT, USA
\end{abstract}

Keywords: DNA methyltransferase, basidiomycetes, Pleurotus ostreatus, mushroom development, DNA methyltransferase inhibitor

\section{A corrigendum on}

Comparative Analysis of DNA Methyltransferase Gene Family in Fungi: A Focus on Basidiomycota

by Huang, R., Ding, Q., Xiang, Y., Gu, T., and Li, Y. (2016). Front. Plant Sci. 7:1556. doi: 10.3389/ fpls.2016.01556

Reason for Corrigendum:

There was an error in the literature cited for the use of ACTIN as the reference gene for the qPCR analysis in "Materials and Methods" section. In the sentence "Results were analyzed by using the $\Delta \Delta C T$ (Livak and Schmittgen, 2001) method using ACTIN (Castanera et al., 2012) as the internal control.", "Castanera et al., 2012" should be replaced with "Fernández-Fueyo et al., 2014; Pezzella et al., 2013." However, the original error or the corrigendum does not change the scientific conclusions of the publication.

In addition, in the original article we have neglected to thank the financial support from National Natural Science Foundation of China, grant number 31672123 to TG. The authors apologize for this oversight.

\section{REFERENCES}

Fernández-Fueyo, E., Castanera, R., Ruiz-Dueñas, F. J., López-Lucendo, M. F., Ramírez, L., Pisabarro, A. G., et al. (2014). Ligninolytic peroxidase gene expression by Pleurotus ostreatus: differential regulation in lignocellulose medium and effect of temperature and pH. Fungal Genet. Biol. 72, 150-161. doi: 10.1016/j.fgb.2014.02.003

Pezzella, C., Lettera, V., Piscitelli, A., Giardina, P., and Sannia, G. (2013). Transcriptional analysis of Pleurotus ostreatus laccase genes. Appl. Microbiol. Biotechnol. 97, 705-717. doi: 10.1007/s00253-012-3980-9

Conflict of Interest Statement: The authors declare that the research was conducted in the absence of any commercial or financial relationships that could be construed as a potential conflict of interest.

Copyright (๑) 2017 Huang, Ding, Xiang, Gu and Li. This is an open-access article distributed under the terms of the Creative Commons Attribution License (CC BY). The use, distribution or reproduction in other forums is permitted, provided the original author(s) or licensor are credited and that the original publication in this journal is cited, in accordance with accepted academic practice. No use, distribution or reproduction is permitted which does not comply with these terms. 